\title{
Invasive Marine and Estuarine Animals of the South Atlantic and Puerto Rico
}

by Gary L. Ray

PURPOSE: New species of estuarine and marine animals are inadvertently or intentionally introduced into the waters of the United States every year (Figure 1). Variously referred to as introduced, nonindigenous (NIS), alien, nonnative, or exotic species, most pose little or no threat; however, a few have the potential to disrupt local ecosystems, fisheries, and human infrastructure. Such invasions directly impact the mission of the U.S. Army Corps of Engineers (USACE) through its responsibilities for construction and maintenance of harbors, ports, and waterways; erosion control; management of water resources; and wetland and coastal habitat restoration. The general biology and ecology of invasive estuarine and marine animals have been described in previous reports (Carlton 2001, Ray 2005). This report is part of a series describing the biology and ecology of known invasive estuarine and marine animals in the major geographic regions of the United States. Invasive animals of the South Atlantic region including Puerto Rico are described and examples of species posing a specific threat to USACE activities are identified.

BACKGROUND: Invasive species are officially defined as "alien species whose introduction does or is likely to cause economic or environmental harm to human health" (Executive Order 13112, Federal Register (1999)). Any species removed from its native range has the potential to become invasive. Within a species' normal range, predation, disease, parasites, competition, and other natural controls act to keep population levels in check (Torchin et al. 2003, Wolfe 2002). Once released from these controls, species abundances have the potential to reach levels that interfere with or displace local fauna. Such effects may occur immediately, after some period of delay, or may never be realized at all depending on the characteristics of the individual species and the conditions into which it is introduced.

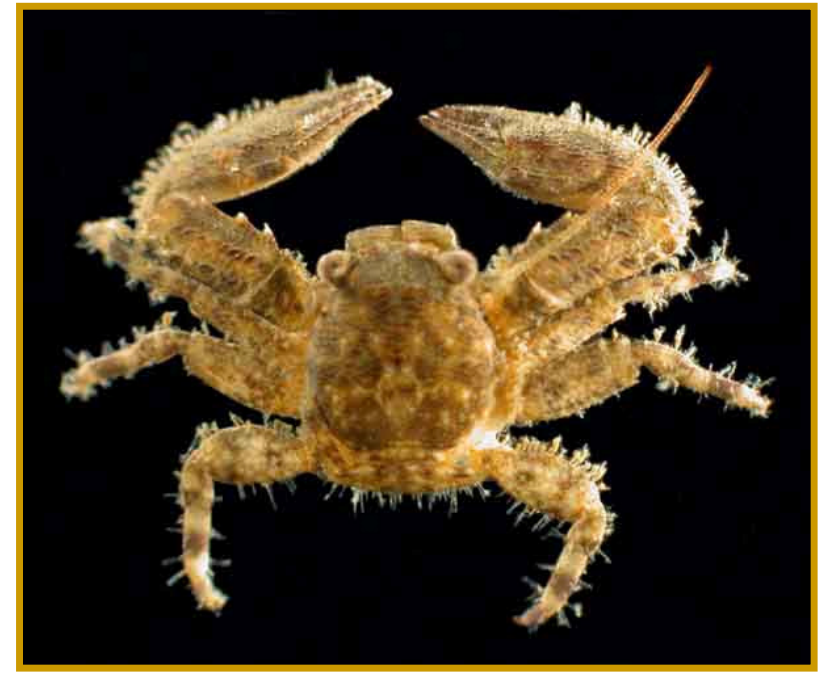

Figure 1. Example of a nonindigenous species, the Green Porcelain Crab, Petrolisthes armatus (image courtesy of Southeast Regional Taxonomic Center)

Lists of estuarine and marine nonindigenous species are often dominated by mollusks, crustaceans, and polychaete worms; however, this may reflect their ease of identification and detection rather than the degree to which they are representative. Ultimately, it is an issue of an organism's biological characteristics (e.g., reproductive capacity, growth rate, etc.) and not its taxonomic affinities that determine if it becomes invasive. Successful invaders tend to be abundant over a large range in their 
native region, have broad feeding and habitat preferences, wide physiological tolerances, short generation times, and high genetic variability (Erlich 1989, Williams and Meffe 1999). Despite the fact that we can identify these characteristics, predicting which species pose the greatest threat remains problematic. While many species possess these characters, most are not obvious in their native range, and the opportunities for introduction and subsequent likelihood of survival are difficult to assess. The situation is further complicated by difficulty in distinguishing invaders from species with naturally wide distributions and those that are cryptogenic; that is, species whose original distributions are uncertain.

Predicting which habitats are likely to be invaded is much simpler. Invaded habitats tend to have low natural diversity, relatively simple (low-connectance) food webs, and a history of recent natural or anthropogenic disturbance (Williams and Meffe 1999). Estuaries and sheltered coastal areas are among the most invaded habitats, presumably due to the fact that they are naturally disturbed, lowdiversity systems, and are historically centers of anthropogenic disturbance associated with navigation, industrial development, and urbanization.

Species can be introduced by a variety of different mechanisms; however, most estuarine and marine species introductions are associated with shipping (Ruiz et al. 2000). Species capable of attaching to hard surfaces may be transported on ship hulls, navigational buoys, floatation devices, anchors, chains, ropes, and flotsam or jetsam (Carlton 2001). During the heyday of wooden-hulled ships, wood borers (e.g., shipworms) and species associated with "dry" ballast such as stones, rock, sand, or other materials were frequently introduced (Carlton and Hodder 1995). Presently, the largest single source of shipping-related introductions is ballast water (Carlton 1985, Lavoie et al. 1999). Ballast water is taken onboard vessels for a variety of purposes related to ship maneuverability and control (Carlton et al. 1995). Animals suspended in the water column or present in bottom sediments are taken in and then introduced to a new location when the ballast is pumped out.

Recently, concerns have also been raised regarding introductions of fish, invertebrates, and "live" rock from the aquarium trade (Padilla and Williams 2004, Weigle et al. 2005). The lionfish Pterois volitans may have been introduced when a private aquarium was demolished in the Miami area during Hurricane Andrew in 1992 (Hare and Whitfield 2003). Other introductions may result from accidental release of animals, inappropriate disposal of packing material by restaurants serving live seafood, and by the live bait industry. Many species have been deliberately introduced to develop new fisheries. For example, the Atlantic striped bass (Morone saxatilis) has been introduced both outside its normal geographic range and in non-native habitats (e.g., reservoirs) in much of the United States.

METHODS: As indicated in the official definition, invasive species are nonindigenous or alien to the region in which they are found. This does not mean that all NIS are invasive, but rather that invasives constitute a subset of NIS. For the purposes of this report, the South Atlantic region is defined as the area from Chesapeake Bay to the Florida Keys including the island of Puerto Rico. In order to create a list of known invasive species within this region, NISBase, a national database of NIS listings maintained by the Smithsonian Institution (www.nisbase.org/nisbase/index.jsp) was queried. Part of the National Exotic Marine and Estuarine Species Information System (NEMESIS), this database permits simultaneous searches of multiple NIS listings. Searches return up to 300 species and include links to individual species' fact sheets and collection data. Queries were 
performed by state and included searches of the U.S. Geological Survey's Nuisance Aquatic Species (NAS) database (http://nas.er.usgs.gov/), the Chesapeake Bay Exotic Marine and Estuarine Species Information System database, and the Nonindigenous Species in the Gulf of Mexico database (http://nis.gsmfc.org/). The resulting lists were amended as necessary after comparison with individual state NIS listings and other reports (Table 1) and then edited to include only estuarine and marine species (Appendix A). Cryptogenic species were not included in this list. Only species known to be invasive or possessing the potential to become invasive are discussed.

RESULTS: A total of 118 nonindigenous estuarine and marine animal species were encountered in listings for the South Atlantic region (Table 2). Fishes and molluscs dominated these lists, with 27 species apiece. At least 11 of the fish species represent deliberate introductions associated with sport fisheries or mariculture operations and include shad and herrings (Alosa aestivalis, A. pseudoharengus, A. sapidissima, Dorosoma cepedianum, and D. petenense), salmon (Onchorhynchus spp. and Salmo salar), cod (Gadus morhua), and striped bass (Morone saxatilis). An additional 15 fish species represent unintentional releases from aquaria including six species of

\begin{tabular}{|c|c|c|c|c|c|c|c|}
\hline \multicolumn{8}{|c|}{\begin{tabular}{|l} 
Table 2 \\
Summary Results for Numbers of South Atlantic NIS by State
\end{tabular}} \\
\hline Species & VA & NC & SC & GA & $\mathrm{FL}$ & PR & \begin{tabular}{|l} 
Total for \\
Region
\end{tabular} \\
\hline Protozoans & 2 & 1 & 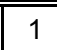 & 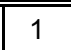 & 1 & & 2 \\
\hline Scyphozoans & 3 & & 1 & & 2 & 1 & 5 \\
\hline Anthozoans & 2 & & & & 2 & & 3 \\
\hline Oligochaetes & 1 & & & & & & 1 \\
\hline Polychaetes & 5 & & & & 3 & & 7 \\
\hline Bivalves & 8 & 1 & & 1 & 7 & & 13 \\
\hline Gastropods & 8 & & & & 4 & & 10 \\
\hline Nudibranchs & 2 & & & & 2 & & 4 \\
\hline Copepods & 2 & 1 & 1 & & 1 & & 2 \\
\hline Barnacles & 2 & 1 & 1 & & 3 & & 4 \\
\hline Amphipods & 6 & & & & 1 & & 7 \\
\hline Isopods & 2 & 1 & 2 & & 3 & & 4 \\
\hline Tanaids & & & & & 1 & & 1 \\
\hline Mysids & 1 & & & & & & 1 \\
\hline Crabs & 2 & 2 & 2 & 2 & 5 & & 8 \\
\hline Shrimp & & & 3 & 1 & 4 & & 4 \\
\hline Insects & 2 & & & & & & 2 \\
\hline Bryozoans & 1 & & & & 2 & & 3 \\
\hline Entoprocts & 2 & & & & & & 2 \\
\hline Tunicates & 9 & & & & 2 & & 9 \\
\hline Fish & 10 & 5 & 2 & 8 & 18 & 1 & 27 \\
\hline Total & 70 & 12 & 13 & 13 & 61 & 2 & 118 \\
\hline
\end{tabular}


angelfish (Pomacanthus sp.), five species of tang (Zebrasoma spp.), spotted scat (Scatophgus argus), blackbelly triggerfish (Rhinecanthus verrucosus), humpback grouper (Cromileptes altivelis), swamp eel, (Monopterus albus) and lionfish (Pterois volitans). Only the lionfish and swamp eel have been recognized as species of concern at this time.

The Pacific oyster, Crassostrea gigas, is another introduced species planted to replace declining stocks of native oysters ( $C$. virginica) in Chesapeake Bay. There is presently considerable debate over the introduction of a second species, the Suminoe oyster, $C$. ariakensis (http://www.chesapeakebay.net/nonnativeoyster.htm). Several species have been unintentionally introduced during shellfish stocking programs including the oyster-disease-causing protozoans Haplosporidium nelsoni and Perkinsus marinus and the Japanese oyster drill Eupleura sulcidentata. Perkinsus (more commonly called Dermo) was first detected in Louisiana in the 1950's and has since spread throughout the Gulf of Mexico and up the east coast as far north as New Jersey.

Geographical distribution of NIS varies widely among states. Florida and Virginia have the greatest number of reported NIS, probably reflecting the extent of coastline, intensity of human influence (e.g., shipping and industrialization), and the existence of NIS monitoring efforts in these states. Most aquatic NIS reported from Puerto Rico are freshwater species and nearly all represent deliberate introductions (Benson et al. 2001). The low number of estuarine and marine NIS presently reported for Puerto Rico may reflect the difficulty in determining the origin of many species or differences in the intensity of monitoring efforts.

DISCUSSION: Species most commonly identified as invasive or listed as of concern in the South Atlantic include Australian spotted jellyfish (Phylloriza punctata), Veined rapa whelk (Rapana venosa), Green-lipped mussel (Perna viridis), Brown mussel (Perna perna), shipworms, Japanese shore crab (Hemigrapsus sanguineus), Green porcelain crab (Petrolisthes armatus), Lionfish (Pterois volitans), and Asian swamp eel (Monopterus albus). Of these species, the biology and ecology of all but shipworms and the swamp eel have been previously described (Ray 2005). Basic information on the swamp eel can be found at the Aquatic Nuisance Species Research Program website (http://el.erdc.usace.army.mil/ansrp/monopterus_albus.htm). These results are briefly summarized below.

\section{Potential Threats to Infrastructure}

Mussels: The Asian green mussel Perna viridis, a native of the tropical Indo-Pacific, has been collected from Tampa Bay to Charlotte Harbor, Florida as well as Kingston Harbor, Jamaica (Buddo et al. 2003). It has planktonic larvae capable of settling on almost any hard surface. The initial discovery of this species in Tampa Bay was due largely to the fact it was clogging water intake pipes at local power plants (Gulf States Marine Commission 2003). It fouls navigation buoys and ship hulls, interferes with shellfish culture, and displaces local fauna. This species could also potentially harbor algal species that produce toxic shellfish poisoning (Buddo et al. 2003). A close relative, the brown mussel (P. perna) is also a potential fouling threat. Native to South Africa, it has successfully invaded South America from Uruguay to the Caribbean and is now distributed from Freeport, Texas to Veracruz, Mexico (Hicks and Tunnel 1993, 1995, Hicks et al. 2001). Slightly smaller than its congener, the brown mussel shares most of its biological characteristics. Its planktonic larvae reside in the water column for up to three weeks potentially allowing it to invade much of the Gulf of 
Mexico and the Florida Keys. Like the green-lipped mussel, it can settle on almost any hard surface and has been reported from jetties, navigational buoys, oil platforms, and natural hard bottom substrates (Hicks and Tunnell 1995).

An additional 26 NIS species (22 percent) can also be classified as fouling species. Most likely introduced on ships' hulls or in ballast water, they include three anemones, four barnacles, three bryozoans, two entoprocts, nine tunicates, two polychaetes, and three bivalves (Appendix A). None of these species have been listed as species of immediate concern.

Molluscs: Four species of wood-boring bivalve molluscs, commonly called shipworms, are present in the South Atlantic. The native range of Teredo bartschi extends from Texas to South Carolina. It is now found in Chesapeake Bay and occasionally as far north as New Jersey. The native ranges of two other Teredo species, $T$. furcifera and $T$. navalis, are uncertain, but both now have cosmopolitan distributions. Lyrodus medilobatus, an Indo-Pacific species detected at Cape Canaveral in 1995, was probably introduced on a fouled ship hull (USGS 2005). Shipworms are generally tolerant of a wide range of salinities, temperatures, flow conditions, and oxygen concentrations. These filter-feeding molluscs are dispersed by planktonic larvae. The larvae settle and construct extensive burrow systems on any wooden structures (e.g., boat hulls, marinas, docks, and pilings). Cohen and Carlton (1995) report that shipworms caused $\$ 615$ million in damage in San Francisco Bay during a 1920's outbreak. Likewise, severe damage was reported in Barnegat Bay, New Jersey and Long Island Sound, New York following outbreaks of T. bartschi associated with increased water temperatures and salinities in power station effluents (Hoagland 1983). Effective control of these pests can be accomplished by chemical treatment (e.g., creosote) of wood or use of alternative materials (Highley 1999).

\section{Potential Threats to Habitat Restoration}

Veined rapa whelk: Rapana venosa, the Veined rapa whelk, a native of the Sea of Japan, was first detected in Chesapeake Bay in 1998 (Mann and Harding 2000). Already known as an invasive species in the Black, Adriatic, and Aegean Seas, it is thought to have entered the United States via ballast water. It prefers hard sandy bottoms with salinities of 18-28 ppt and can reach a total length of $150 \mathrm{~mm}$. While juveniles feed on barnacles, mussels, and newly settled and very young oysters, adults feed heavily on softshell clams (Mya arenaria) and hard clams (Mercenaria mercenaria). The rapa whelk has the potential to affect restoration of shellfish habitat in Chesapeake Bay and elsewhere. Distribution of this species is presently limited to portions of Chesapeake Bay, but it will likely spread north to Cape Cod and south to Cape Hatteras (Mann and Harding 2003).

Australian spotted jellyfish: Australian spotted jellyfish Phylloriza punctata is presently found in abundance only in the northern Gulf of Mexico, but has been reported as far afield as Brevard County, Florida. This large jellyfish (average adult bell width is $35 \mathrm{~cm}$ ) can be found in swarms of up to 500,000 in a $150-\mathrm{km}^{2}$ area. Feeding intensively on zooplankton and fish larvae, these jellyfish represent a potential threat to fisheries and fisheries restoration operations.

Green porcelain crab: The green porcelain crab (Petrolisthes armatus) (Figure 1) is a South American and Caribbean species now distributed as far north as Georgia and South Carolina. Found in rocky intertidal and tidal creek oyster bar habitats, it is presently undergoing large changes in both 
distribution and abundance, reaching densities as high as $10,000 / \mathrm{m}^{2}$ in South Carolina salt marshes (Lohrer 2001). It is unclear whether this represents a natural range expansion or an inadvertent introduction. Hartman et al. (2001) and Hollebone and Hay (2003) suggest that high abundances of $P$. armatus provide an alternative prey for predators of xanthid crabs. Xanthids are important predators of newly settled oysters; therefore, the increase in green porcelain crab indirectly results in a negative impact on oyster populations. Obviously, such an effect has important implications for oyster habitat restoration efforts in the South Atlantic.

Asian swamp eel: The Asian swamp eel Monopterus albus is not a true eel, but a member of the fish family Synbranchidae. Nocturnal in habit, it burrows as deep as $1.5 \mathrm{~m}$ in the bottoms of ponds, streams, rivers, and other freshwater habitats. It can also tolerate both saline and brackish waters. The swamp eel feeds on fishes, worms, crustaceans, and other aquatic species. Marketed as an aquarium species, it may have been introduced accidentally by aquarium release. It is presently found in drainages in southern Florida as well as the Tampa Bay region. It may interfere with USACE operations by displacing native species and its extensive burrow systems may contribute to accelerated drying of shallow water bodies. For more information on this species, see either the ANSRP website (listed above) or the Gulf States Marine Fisheries Commission NIS fact sheet (http://nis.gsmfc.org).

Japanese shore crab: The Japanese shore crab Hemigrapsus sanguineus, a native of the western Pacific Ocean, is characteristically found in low intertidal and subtidal zones with rock or cobble substrates. First detected in New Jersey in 1988 (McDermott 1991), it has since spread north into southern New England (Lohrer and Whitlach 1997) and south into Chesapeake Bay. It has quickly become one of the most abundant crabs in the rocky intertidal zone, displacing native xanthid crabs and even the invasive green crab from areas where their distributions overlap (Lohrer and Whitlach 1997, Jensen et al. 2002). It has an extended breeding season and tolerates salinities as low as $15 \mathrm{ppt}$ as larvae (Epifaunio et al. 1998). Adults appear to prefer salinities of $20 \mathrm{ppt}$ or higher. The Japanese shore crab has broad food preferences including macroalgae, snails, mussels, and barnacles (Lohrer and Whitlach 1997, Bourdeau and O'Connor 1999, Percival and Wilson 2001). While it seems doubtful this species will directly interfere with USACE operations, the issue of incidentally contributing to its spread may arise in situations where riprap or other coarse materials are placed in the intertidal zone.

Wood-boring isopods: Two wood-boring isopods are present in the South Atlantic (Sphaeroma terebrans and $S$. walkeriI), both of which may endanger habitat restoration efforts. The first of these was probably introduced on the hulls of wooden ships. Now found from Brazil to South Carolina and from Liberia to the Congo (Carlton and Ruckelshaus 1997), it burrows into hard substrates including hard-packed sand, and decaying or living wood. There is considerable concern over its potential impact on restoration of mangrove habitat. The isopod burrows into the prop roots of red mangrove (Rhizophora mangle), weakening and ultimately destroying them (Rehm and Humm 1973). This not only damages the individual mangrove plant, but leads to undercutting and erosion of exposed sediments. Impact of the introduction of the southwestern Pacific $S$. walkeri is unknown (Fuller 2005). 
Potential Threats to Human Health. The lionfish Pterois volitans (Figure 2), a native of the Indian Ocean and western Pacific coral reefs, is a favorite aquarium fish because of its colorful appearance. Lionfish bear poisonous dorsal, anal, and pelvic spines. The toxin is painful, but is generally not fatal. It was first noticed in Florida waters in 1994 and may have been introduced when a private aquarium was demolished in the Miami area during Hurricane Andrew in 1992 (Hare and Whitfield 2003). Associated with hard bottoms, coral reefs, and artificial substrates from 26 to $79 \mathrm{~m}$ deep, it is generally found on ledges and crevices from Florida to Cape Hatteras, North Carolina. It has also been reported in Puerto Rico. Lionfish feed mostly upon small fish, crabs, and shrimp; however, their impact on local ecosystems has not been assessed.

\section{Potential Future Threats}

Chinese mitten crab and Asian date mussel: Although yet not reported from the South Atlantic, two species are of particular concern in this region. These include the Chinese mitten crab Eriocheir sinensis and the Asian date mussel Musculista senhousia. The mitten crab first appeared as an invasive species in Germany during the early 1900's and has since spread through most of Europe (Clark et al. 1998) and is now in the United States. It is reported from Lake Erie, San Francisco Bay, the Columbia River, and Mississippi Sound. The crabs are catadromous, spending most of their adult life in freshwater, then returning to the sea only to reproduce. They form extensive burrows in the riverbanks and levees, thus posing a direct threat to earthen water control structures. Further information on the life history of mitten crabs can be found in Veldhuizen and Stanish (2002), an ASN fact sheet (http://el.erdc.usace.army.mil/ansrp/eriocheir_sinensis.htm), and in Ray (2005).

The Asian date mussel, native to intertidal and subtidal sediments from Siberia to the Red Sea, is now found in Australia, New Zealand, the eastern Mediterranean, and southern France (Crooks 1996). It was probably introduced into the state of Washington during introduction of oysters in 1924 and has since spread to Southern California. It produces planktonic larvae that can remain in the water column as long as 55 days, then settle onto muddy or sandy substrates. It forms dense beds that alter both sediment composition and native benthic assemblages (Crooks 1998, Crooks and Khim 1999). Success of seagrass restoration projects can be compromised in heavily infested areas (Reutsch and Williams 1998). Additional information on this species can be found in Ray (2005).

Nuclear worm: One species, not listed as an NIS, but recently offered by some live bait dealers in the Chesapeake Bay area, is the so-called "nuclear worm." A very large, bright pink polychaete reaching lengths of $2 \mathrm{~m}$, it is a native of Viet Nam (Ward 2002). Although often referred to as Namalycastis abiuma, a recent taxonomic revision indicates that neither this species nor any of its 
variants reach lengths more than 1 in. (Glasby 1999). It seems highly likely that this animal represents an undescribed species. It is probably not a threat as an introduced species because it cannot survive temperatures below $20^{\circ} \mathrm{C}\left(68^{\circ} \mathrm{F}\right)$ (Ward 2002).

ACKNOWLEDGEMENTS: This review was sponsored by the U. S. Army Engineer Research and Development Center, Vicksburg, MS, under the Aquatic Nuisance Species Research (ANSRP) Program.

POINTS OF CONTACT: For additional information, contact Dr. Gary L. Ray (601-634-2589, Gary.Ray@erdc.usace.army.mil) or the Program Manager of the Aquatic Nuisance Species Research (ANSRP) Program, Mr. Glenn Rhett (601-634-3717), Glenn.G.Rhett@,erdc.usace.army.mil. This technical note should be cited as follows:

Ray, G. L. (2005). "Invasive estuarine and marine animals of the South Atlantic and Puerto Rico," ANSRP Technical Notes Collection (ERDC TN-ANSRP-05-5), U.S. Army Engineer Research and Development Center, Vicksburg, MS. http://el.erdc.usace.army.mil/ansrp

\section{REFERENCES}

Benson, A. J., Fuller, P. L., and Jacono, C. C. (2001). "Summary report of nonindigenous aquatic species in U.S. Fish and Wildlife Service Region 4," United States Geological Survey, Florida Caribbean Science Center. Available online at http://cars.er.usgs.gov/Region_4_Report/R4finalreport.pdf.

Bourdeau, P. E., and O'Connor, N. J. (1999). "Prey preferences of the recently-introduced Western Pacific shore crab, Hemigrapsus sanguineus, feeding on molluscs and macroalgae in southeastern Massachusetts." First National Conference on Marine Bioinvasions. Cambridge, MA. January 24-27, 1999. Available online at http://massbay.mit.edu/ exoticspecies/conferences/1999.

Buddo, D., Steele, R. D., and D’Oyen, E. R. (2003). "Distribution of the invasive indo-pacific Green Mussel, Perna viridis, in Kingston Harbour, Jamaica," Bulletin of Marine Science 73, 433-441.

Carlton, J. T. (1985). "Transoceanic and intraoceanic dispersal of coastal marine organisms: The biology of ballast water," Oceanography and Marine Biology: An Annual Review 23, 313-374.

Carlton, J. T. (2001). Introduced Species in U.S. Coastal Waters: Environmental Impacts and Management Priorities. Pew Oceans Commission, Arlington, VA. Available at http://www.pewtrusts.org/pdf/env_oceans_species.pdf.

Carlton, J. T., and Hodder, J. (1995). "Biogeography and dispersal of coastal marine organisms: Experimental studies on a replica of a $16^{\text {th }}$ century sailing vessel," Marine Biology 121, 721-730.

Carlton, J. T., and Ruckleshaus, M. H. (1997). "Nonindigenous marine invertebrates and algae." Strangers in Paradise. Impact and Management of Nonindigenous Species in Florida. D. Simberloff, C. Schmitz, and T. C. Brown, ed., Island Press, Washington, DC, 187-201.

Carlton, J. T., Reid, D. M., and van Leeuwen, H. (1995). "Shipping Study. The role of shipping in the introduction of nonindigenous aquatic organisms to the coastal waters of the United States (other than the Great Lakes) and an analysis of control options," The National Sea Grant College Program/Connecticut Sea Grant Project R/ES-6, Report No. CG-D-11-95. 
Clark, P. F., Rainbow, P. S., Robbins, R. S., Smith, B., Yeomans, W. E., Thomas, M., and Dobson, A. G. (1998). “The alien Chinese Mitten Crab, Eriocheir sinensis (Crustacea: Decapoda: Brachyura), in the Thames catchment," Journal of the Marine Biological Association of the United Kingdom 78, 1215-1221

Cohen, A. N., and Carlton, J. T. (1995). "Biological Study. Nonindigenous aquatic species in a United States estuary: A case study of the biological invasions of the San Francisco Bay and Delta," a report for the United States Fish and Wildlife Service, Washington, DC, and the National Sea Grant Program, Connecticut Sea Grant Publication PB96166525. Available online at http://www.anstaskforce.gov/sfinvade.htm.

Crooks, J. A. (1996). "The population ecology of an exotic mussel, Musculista senhousia, in a Southern California bay," Estuaries 19, 42-50.

Crooks, J. A. (1998). "Habitat alteration and community-level effects of an exotic mussel, Musculista senhousia," Marine Ecology Progress Series 162, 137-152.

Crooks, J. A., and Khim, H. S. (1999). "Architectural vs. biological effects of a habitat-altering, exotic mussel, Musculista senhousia," Journal of Experimental Marine Biology and Ecology 240, 53-75.

Epifaunio, C. E., Dittel, A. I., Park, S., Schwalm, S., and Fouts, A. (1998). "Early life history of Hemigrapsus sanguineus, a non-indigenous crab in the Middle Atlantic Bight(USA)," Marine Ecology Progress Series 170, 231238 .

Erlich, P. R. (1989). “Attributes of Invaders and the invading processes: Vertebrates.” Biological Invasions: A Global Perspective. J. A. Drake et al., ed., 1989 SCOPE. John Wiley and Sons, Ltd, 315-328. Available online at http://www.icsu-scope.org/downloadpubs/scope37/scope37.html.

Federal Register. (1999). Executive Order 13112 of February 3, 1999-Invasive Species. Federal Register 64, No. 25. Available online at $h t t p: / / w w w . i n v a s i v e s p e c i e s . g o v / l a w s$.

Fuller, P. (2005). Sphaeroma walkeri. Nonindigenous Aquatic Species Database, Gainesville, FL. Available online at http://nas.er.usgs.gov/queries/factsheet.asp?SpeciesID $=1084$.

Glasby, C. J. (1999). "The Namanereidinae (Polychaeta: Nereididae). Part I. Taxonomy and Phylogeny," Records of the Australian Museum 25, 1-129.

Gulf States Marine Commission. (2003). "Non-Native Aquatic Species in the Gulf of Mexico and South Atlantic Regions." Available online at http://nis.gsmfc.org/.

Hare, J. A., and Whitfield, P. E. (2003). An integrated assessment of the introduction of Lionfish (Pterois volitans/miles complex) to the Western Atlantic Ocean. National Atmospheric and Oceanographic Administration, National Ocean Service Technical Memorandum CCFHR 1.

Hartman, M. J., Stancyk, S E., and Lohrer, A. M. (2001). “An invasive crab, Petrolisthes armatus, as alternative prey in an oyster reed ecosystem." $16^{\text {th }}$ Biennial Conference of the Estuarine Research Federation, November 4-8, 2001. St. Petersburg Beach, FL. Available online at http://erf.org/erf2001.

Hicks, D. W., and Tunnell, J. W., Jr. (1993). "Invasion of the south Texas coast by the edible brown mussel Perna perna (Linnaeus, 1758)," Veliger 36, 92-94.

Hicks, D. W., and Tunnell, J. W., Jr. (1995). "Ecological notes and patterns of dispersal in the recently introduced mussel, Perna perna (Linne 1758), in the Gulf of Mexico," American Malacological Bulletin 11, 203-206.

Hicks, D. W., Tunnell, J. W., Jr., and McMahon, R. F. (2001). "Population dynamics of the nonindigenous brown mussel Perna perna in the Gulf of Mexico compared to other worldwide populations," Marine Ecology Progress Series 211, 181-192. 
Highley, T. L. (1999).."Biodeterioration of wood." Wood handbook--Wood as an engineering material. Gen. Tech. Rep. FPL-GTR-113, U.S. Department of Agriculture, Forest Service, Forest Products Laboratory, Madison, WI. Available online at $h t t p: / / w w w . f p l . f s . f e d . u s / d o c u m n t s / f p l g t r / f p l g t r 113 / c h 13 . p d f$.

Hoagland, K. E. (1983). Life history characteristics and physiological tolerances of Teredo bartschi, a shipworm introduced into two temperate zone nuclear power plant effluents. Hemisphere Publishing Co., Miami Beach, FL, 609-622.

Hollebone, A. L., and Hay, M. E. (2003). "An invasive crab in the South Atlantic Bight; friend or foe?" Third International Conference on Bioinvasions. March 16-19, 2003, La Jolla, CA. Available online at http://massbay.mit.edu/exoticspecies/conferences/2003.

Jensen, G. C., McDonald, P. S., and Armstrong, D. A. (2002). "East meets west: Competitive interactions between green crab Carcinus maenas, and native and introduced shore crab Hemigrapsus sp." Marine Ecology Progress Series $225,251-262$.

Lavoie, D. M., Smith, L. D., and Ruiz, G. M. (1999). "The potential for intracoastal transfer of nonindigenous species in the ballast water of ships," Estuarine, Coastal and Shelf Science 48, 551-654.

Lohrer, A. M. (2001). "The threat of invasion in South Carolina estuaries: A focus of exotic decapod crabs." $16^{\text {th }}$ Biennial Conference of the Estuarine Research Federation, November 4-8, 2001. St. Petersburg Beach, FL. Available online at http://www.erf.org/erf2001/.

Lohrer, A. M., and Whitlach, R. B. (1997). "Ecological studies on the recently introduced Japanese Shore Crab (Hemigrapsus sanguineus), in Eastern Long Island Sound." Proceedings of the $2^{\text {nd }}$ Northeast Conference on Nonindigenous Aquatic Nuisance Species. Connecticut Sea Grant Publication CTSG-97-02, 49-60.

Mann, R., and Harding, J. M. (2000). "Invasion of the North American Atlantic Coast by a large predatory Asian mollusk," Biological Invasions 2, 7-22.

Mann, R., and Harding, J. M. (2003). "Salinity tolerance of larval Rapana venosa: implications for dispersal and establishment of an invading predatory gastropod on the North American Atlantic coast," Biological Bulletin 204, 96-103.

McDermott, J. J. (1991). "A breeding population of the Western Pacific crab Hemigrapsus sanguineus (Crustacea: Decapoda: Grapsidae) established on the Atlantic coast of North America," Biological Bulletin 181, 195-198.

Nature Conservancy. (2004). Website. http://nature.org/wherewework/northamerica/states/northcarolina/initiatives/.

Padilla, D. K., and Williams, S. L. (2004). "Beyond ballast water: aquarium and ornamental trades as sources of invasive species in aquatic ecosystems," Frontiers in Ecology and the Environment 3, 131-138.

Percival, S. R., and Wilson, K. (2001). "Feeding and substrate preferences of the Japanese shore crab, Hemigrapsus sanguineus." Second International Conference on Marine Bioinvasions. New Orleans, LA. April 9-11, 2001. Available online at $h t t p: / / m a s s b a y . m i t . e d u / e x o t i c s p e c i e s / c o n f e r e n c e s / 2001 /$.

Ray, G. L. (2005) "Invasive animal species in marine and estuarine environments: Biology and ecology." Technical Report ERDC/EL TR-05-2, U.S. Army Engineer Research and Development Center, Vicksburg, MS.

Rehm, A. and Humm, H. J. (1973). "Sphaeroma terebrans: A threat to the mangroves of Southwestern Florida," Science $182,173-174$.

Reutsch, T. B. H., and Williams, S. L. (1998). "Variable response of native eelgrass Zostera marina to a nonindigenous bivalve Musculista senhousia," Oecologia 113, 428-441. 
Ruiz, G. M., Fofonoff, P., Carlton, J. T., Wonham, M. J., and Hines, A. H. (2000). "Invasion of coastal marine communities in North America: Apparent patterns, processes, and biases," Annual Review in Ecology and Systematics 2000, 481-531.

Torchin, M. E., Lafferty, K. D., Dobson, A. P., McKensie, V. J., and Kuris, A. M. (2003). "Introduced species and their missing parasites," Nature 421, 628-630.

U.S. Environmental Protection Agency. (2000). "An initial survey of aquatic invasive species issues in the Gulf of Mexico region.” Invasive Species Focus Team, Gulf of Mexico Program. EPA 855-R-00-003. Available online at http://nis.gsmfc.org/.

U.S. Geological Survey. (2003). "South Florida Restoration Science Forum Website," available online at http://sofia.usgs.gov/sfrsf/rooms/species/invasive/intro/.

U.S. Geological Survey. (2005). "Nonindigenous Aquatic Species Database,” Gainesville, FL. http://nas.er.usgs.gov

University of Georgia. (2002). "Invasive and other exotic species of North America," available online at http://www.invasive.org/.

Veldhuizen, T., and Stanish, S. (2002). "Overview of the life history, distribution, abundance, and impacts of Chinese mitten crab Eriocheir sinensis." Appendix A, A Draft National Management Plan for the Genus Eriocheir. Aquatic Nuisance Species Task Force. February 2002. 37-5. Available online at http://www.anstaskforce.gov/.

Ward, L. (2002). "More on Namalycastis" Annelida List Server Archives, August 5, 2002. Available online at http://www.bio.net/hypermail/annelida/2002-August/002012.html.

Weigle, S. M., Smith, L. D., Carlton, J. T., and Pederson, J. (2005). "Assessing the risk of introducing exotic species via the live marine species trade," Conservation Biology 19, 213-223.

Williams, J. D., and Meffe, G. K. (1999). "Nonindigenous species." Status and trends of the nation's biological resources. U.S. Geological Survey. Available online at $h t t p: / / b i o l o g y . u s g s . g o v / s+t / S N T / i n d e x . h t m$.

Wolfe, L. M. (2002). "Why alien invaders succeed: Support for the escape-from-enemy hypothesis," American Naturalist 160, 705-711.

NOTE: The contents of this technical note are not to be used for advertising, publication, or promotional purposes. Citation of trade names does not constitute an official endorsement or approval of the use of such products. 
ERDC/TN ANSRP-05-5

September 2005

\section{APPENDIX A: NIS LISTINGS BY STATE FOR THE SOUTH ATLANTIC REGION AND PUERTO RICO}

\begin{tabular}{|c|c|c|c|c|c|c|c|}
\hline Species & Group & VA & NC & SC & GA & FL & PR \\
\hline Perkinsis marinus & Protozoa & VA & NC & SC & GA & FL & \\
\hline Haplosporisium nelsoni & Protozoa & $\mathrm{VA}$ & & & & & \\
\hline Nematostella vectensis & Anthozoa & VA & & & & & \\
\hline Diadumene lineata & Anthozoa & $V A$ & & & & FL & \\
\hline Haliplanella lineata & Anthozoa & & & & & FL & \\
\hline Blackfordia virginica & Hydrozoa & VA & & & & & \\
\hline Maeotias inexspectata & Hydrozoa & VA & & Sc & & & \\
\hline Maeotias marginata & Hydrozoa & VA & & & & & \\
\hline Phyllorhiza punctata & Scyphozoa & & & & & $\mathrm{FL}$ & PR \\
\hline Tubificoides heterochaetus & Oligochaete & VA & & & & & \\
\hline Boccardiella ligerica & Polychaete & VA & & & & $\mathrm{FL}$ & \\
\hline Demonax flecatus & Polychaete & VA & & & & & \\
\hline Demonax sp. & Polychaete & VA & & & & & \\
\hline Ficopomatomus enigmaticus & Polychaete & VA & & & & & \\
\hline Hydroides elegans & Polychaete & & & & & FL & \\
\hline Namanereis littoralis & Polychaete & VA & & & & & \\
\hline Polydora cornuta & Polychaete & & & & & FL & \\
\hline Crassostrea ariakensis & Bivalve & VA & & & & & \\
\hline Crassostrea gigas & Bivalve & VA & & & & & \\
\hline Cyrenoida floridana & Bivalve & VA & & & & & \\
\hline Ischadium recurvum & Bivalve & VA & & & & & \\
\hline Lyrodus medilobatus & Bivalve & & & & & $\mathrm{FL}$ & \\
\hline Mytella charruana & Bivalve & & & & & $\mathrm{FL}$ & \\
\hline Perna viridis & Bivalve & & & & GA & FL & \\
\hline Pinctada margaritfera & Bivalve & & & & & FL & \\
\hline Rangia cuneata & Bivalve & VA & $\mathrm{NC}$ & & & $\mathrm{FL}$ & \\
\hline Tridacna crocera & Bivalve & & & & & FL & \\
\hline Tridacna maxima & Bivalve & & & & & $\mathrm{FL}$ & \\
\hline Teredo bartschi & Bivalve & VA & & & & & \\
\hline Teredo furcifera & Bivalve & VA & & & & & \\
\hline Teredo navalis & Bivalve & VA & & & & & \\
\hline Assiminea succinea & Gastropod & VA & & & & & \\
\hline Eupleura sulcidentata & Gastropod & VA & & & & & \\
\hline Littorina littorea & Gastropod & VA & & & & $\mathrm{FL}$ & \\
\hline Melampus floridanus & Gastropod & VA & & & & & \\
\hline Melanoides tuberculatus & Gastropod & & & & & $\mathrm{FL}$ & \\
\hline Myostella myosotis & Gastropod & VA & & & & $\mathrm{FL}$ & \\
\hline Rapana vensoa & Gastropod & VA & & & & & \\
\hline Stramonita haemastoma & Gastropod & VA & & & & & \\
\hline Truncatella subcylindrica & Gastropod & & & & & $\mathrm{FL}$ & \\
\hline Vitrinella floridana & Gastropod & VA & & & & & \\
\hline
\end{tabular}


ERDC/TN ANSRP-05-5

September 2005

\begin{tabular}{|c|c|c|c|c|c|c|c|}
\hline Species & Group & VA & NC & sc & GA & FL & PR \\
\hline Cuthona oerca & Nudibranch & & & & & FL & \\
\hline Ercolania fuscovittata & Nudibranch & & & & & FL & \\
\hline Placida dendritica & Nudibranch & VA & & & & & \\
\hline Tenellia adspersa & Nudibranch & VA & & & & & \\
\hline Argulus japonicus & Copepod & VA & & & & FL & \\
\hline Eurytemora affinis & Copepod & VA & NC & SC & & & \\
\hline Balanus amphitrite & Barnacle & VA & NC & SC & & $F L$ & \\
\hline Balanus reticularis & Barnacle & & & & & FL & \\
\hline Balanus trigonus & Barnacle & & & & & $F L$ & \\
\hline Loxothylacus panopaei & Barnacle & VA & & & & & \\
\hline Amphilochus sp. & Amphipod & VA & & & & & \\
\hline Apocorophium acutum & Amphipod & VA & & & & & \\
\hline Chelura terebrans & Amphipod & & & & & $F L$ & \\
\hline Monocorophium acheruscium & Amphipod & VA & & & & & \\
\hline Monocorophium insidiosum & Amphipod & VA & & & & & \\
\hline Gitanopsis sp. & Amphipod & VA & & & & & \\
\hline Stenothoe gallensis & Amphipod & VA & & & & & \\
\hline Ligia exotica & Isopod & VA & NC & SC & & FL & \\
\hline Sphaeroma terebrans & Isopod & VA & & & & FL & \\
\hline Sphaeroma walkeri & Isopod & & & & & $F L$ & \\
\hline Synidotea laevaidorsalis & Isopod & & & SC & & & \\
\hline Zeuxo maledivensis & Tanaid & & & & & FL & \\
\hline Americamysis almyra & Mysid & VA & & & & & \\
\hline Callinectes bocourti & Crab & & $\mathrm{NC}$ & SC & & FL & \\
\hline Callinectes exasperatus & Crab & & & & GA & & \\
\hline Carcinus maenas & Crab & VA & & & & & \\
\hline Charybdis helleri & Crab & & & & & FL & \\
\hline Hemigrapsus sanguineus & Crab & VA & NC & & & & \\
\hline Petrolisthes armatus & Crab & & & SC & GA & FL & \\
\hline Platychirograpsus spectabilis & Crab & & & & & $F L$ & \\
\hline Scylla serrata & Crab & & & & & $F L$ & \\
\hline Macrobrachium olfersi & Shrimp & & & & & $F L$ & \\
\hline Penaeus monodon & Shrimp & & & SC & GA & $F L$ & \\
\hline Penaeus stylirostris & Shrimp & & & SC & & $\mathrm{FL}$ & \\
\hline Penaeus vannanmei & Shrimp & & & SC & & FL & \\
\hline Placopsidella grandis & Insect & VA & & & & & \\
\hline Anisolabis maritima & Insect & VA & & & & & \\
\hline Bugula neritina & Bryozoan & VA & & & & & \\
\hline Sunanella sbogae & Bryozoan & & & & & $F L$ & \\
\hline Victorella pavida & Bryozoan & & & & & $F L$ & \\
\hline Barentsia benedini & Ectoproct & VA & & & & & \\
\hline Loxosomatoides laevis & Ectoproct & VA & & & & & \\
\hline Ascidella aspersa & Tunicate & VA & & & & & \\
\hline Botrylloides violacteus & Tunicate & VA & & & & & \\
\hline Botryllus schosseri & Tunicate & VA & & & & FL & \\
\hline
\end{tabular}


ERDC/TN ANSRP-05-5

September 2005

\begin{tabular}{|c|c|c|c|c|c|c|c|}
\hline Species & Group & VA & NC & sc & GA & FL & PR \\
\hline Diplosoma listerianum & Tunicate & VA & & & & & \\
\hline Ecteinascidia turniata & Tunicate & VA & & & & & \\
\hline Mogula manhatetensis & Tunicate & VA & & & & & \\
\hline Styela clavata & Tunicate & VA & & & & & \\
\hline Styela canopus & Tunicate & VA & & & & & \\
\hline Styela plicata & Tunicate & VA & & & & FL & \\
\hline Alosa aestivalis & Fish & VA & $\mathrm{NC}$ & & GA & & \\
\hline Alosa pseudoharengus & Fish & VA & & & GA & & \\
\hline Alosa sapidissima & Fish & VA & & & GA & FL & \\
\hline Anguilla rostrata & Fish & & $\mathrm{NC}$ & & & & \\
\hline Cromileptes altivelis & Fish & & & & & FL & \\
\hline Dorosoma cepedianum & Fish & VA & & & GA & & \\
\hline Dorosoma petenense & Fish & VA & & & GA & FL & \\
\hline Gadus morhua & Fish & VA & & & & & PR \\
\hline Monopterus albus & Fish & & & & GA & FL & \\
\hline Morone saxatilis & Fish & VA & & SC & GA & FL & \\
\hline Oncorhynchus kisutch & Fish & VA & & & & & \\
\hline Oncorhynchus nerka nerka & Fish & & $\mathrm{NC}$ & & & & \\
\hline Oncorhynchus tshawytscha & Fish & VA & & & & & \\
\hline Pomacanthus annularis & Fish & & & & & FL & \\
\hline Pomacanthus asfur & Fish & & & & & FL & \\
\hline Pomacanthus imperator & Fish & & & & & FL & \\
\hline Pomacanthus maculosus & Fish & & & & & FL & \\
\hline Pomacanthus semicircularis & Fish & & & & & FL & \\
\hline Pomacanthus xanthometopon & Fish & & & & & FL & \\
\hline Pterois volitans & Fish & & $\mathrm{NC}$ & & GA & FL & \\
\hline Rhinecanthus verrucosus & Fish & & & & & FL & \\
\hline Salmo salar & Fish & VA & $\mathrm{NC}$ & SC & & & \\
\hline Scatophagus argus & Fish & & & & & FL & \\
\hline Zebrasoma desjardinii & Fish & & & & & FL & \\
\hline Zebrasoma flavescens & Fish & & & & & $\mathrm{FL}$ & \\
\hline Zebrasoma veliferum & Fish & & & & & FL & \\
\hline Zebrasoma xanthurum & Fish & & & & & FL & \\
\hline
\end{tabular}

